\title{
KommentTi
}

\section{Vapaus ja vastavuoroinen tunnustus työssä}

Työyhteisön kuuluu yhdessä sopia omista arvoistaan, tavoitteistaan ja pelisäännöistään. Samoin on sovittava, millä perustein tunnustus annetaan kunkin panoksesta yhteiseen hyvään.

HEIKKI PASANEN JA MERJA ALANKO-TURUNEN tarkastelevat artikkelissaan tunnustusta työn kontekstissa, jossa yksilöiden välinen suhde on institutionaalisten roolien, esimies-alaissuhteen välittämä. He puhuvat vertaisuuden tunnustamisesta. Ilmaisu juontunee tutkimuskohteena olevasta interventiomenetelmästä, vertaisryhmämentoroinnista.

On kuitenkin ongelmallista puhua filosofi Georg Wilhelm Friedrich Hegelin, saati "Hegelin kirjassaan esittämästä, tunnustuskäsitteestä”. Hegel kehitteli tunnustuksen käsitettä läpi uransa eri teoksissaan, ja niistä on vaikea esittää yhtä tulkintaa.

Filosofi Robert Williamsin perusteellinen teos aiheesta (1977) kritisoi muun muassa hegeliläisen poliittisen filosofin Alexandre Kojèven, yhteiskuntateoreetikko Jürgen Habermasin, filosofi ja sosiologi Axel Honneth Honnethin ja filosofi Ludwig Siepin tulkintoja Hegelin tunnustuksen käsitteestä ja herraorja-dialektiikasta

HEGELIN HENGEN FENOMENOLOGIA ja poliittinen teoria tutkii vapauden historiallisten, poliittisten ja institutionaalisten edellytysten kehitystä ennen muuta Euroopan historiassa. Jotkut tutkijat katsovat, että herran ja orjan dialektiikka analysoi feodaalista maaorjuusjärjestelmää (Cole 2004) ja varhaiskapitalistisia orjanomistusjärjestelmiä (Buck-Morss, 2009) siirtymävaiheena moderniin perustuslailliseen valtioon, jossa kaikkien kansalaisten oikeudet on tunnustettu.

Hegel seurasi tarkasti oman aikansa politiikkaa ja todisti muun muassa orjakapinaa, joka käynnistyi vuonna 1791 Ranskan rikkaimmassa siirtomaassa
Saint-Dominiguessa ja johti Haitin tasavallan syntyyn vuonna 1804 . Sen perustuslaki turvasi kaikille kansalaisille rotuun katsomatta kansalaisoikeudet.

Yhdysvallat pelkäsi Haitin esimerkin leviävän alueelleen, ja Napoleon päätti palauttaa orjuuden valtameren takaisiin siirtomaihin lähettäen kenraali Philippe Leclercin johtaman laivaston Haitiin. Keltakuume ja haitilaisten vastarinta löivät ranskalaiset, mutta tasavalta hajosi pitkään kestäneiden sotien tuloksena kahteen sotaherrojen hallitsemaan osaan. Orjakapina, jonka yksi tunnus oli "vapaus tai kuolema”, oli esikuvana Latinalaisen Amerikan kolonialismin vastaisille liikkeille.

TOINEN TULKINTAPA on irrottautua historiallisesta kontekstista ja nähdä tunnustus yksilön vapauden ja itsetietoisuuden yleisenä edellytyksenä. Yksilö voi tulla tietoiseksi vapaudestaan ja itsestään vain, jos niin ikään vapaa henkilö tai yhteisö tunnustaa tämän vapauden. Itsetietoisuus ja identiteetin muodostuminen ovat perustavasti riippuvaisia sosiaalisesta yhteisöstä. Tätä tulkintalinjaa edustaa niin kutsuttu nykyaikainen tunnustusteoria, jonka katsotaan syntyneen 1990-luvulla Charles Taylorin esseestä "Politics of recognition" (1992) ja Honnethin teoksesta The Struggle for Recognition. Honnethin teos The Moral Grammar of Social Conflicts (1996) nojautui Hegelin Oikeusfilosofiassa esittämään teoriaan eettisestä järjestyksestä (Sittlickeit, siveellisyys) ja etsi tunnustussuhteille psykologisia perusteita George Herbert Meadin sosiaalipsykologiasta ja Donald Winnicotin psykoanalyyttisesta teoriasta lapsen kehityksestä.

Honneth (1996) tarkastelee tunnustussuhteita perheessä, valtiossa ja kansalaisyhteiskunnassa. Hän kutsuu niitä 'rakkaudeksi', 'itsekunnioitukseksi' ja 'itsearvostukseksi'. Yksilö hakee tunnustusta ja rakentaa identiteettiään perheen, työyhteisön ja kansalaisjärjestöjen jäsenenä sekä oikeusvaltion kansalaisena. 


\section{AmMATTIEN JA TYÖN YMPÄRILLE RAKENTUU YHTEISÖJÄ.}

Hegelin innoittama tunnustusteoria puhuu vastavuoroisesta tunnustamisesta. Se korostaa, että tunnustuksen tulee tapahtua osapuolten asemasta riippumatta ja perustua työnjaosta johtuvaan yksilöiden kykyjen ja panoksen erilaisuuteen. Hegelin hengen fenomenologian (1977 [1807], 115-116) herran ja orjan dialektiikkaa koskevissa pykälissä herran ja orjan suhdetta välitti objekti (thing), maaomaisuus, jota orja työllään muokkasi tyydyttääkseen herransa tarpeet ja mielihalut. Tuosta työstä kasvoivat itsetietoisuus ja vaatimus herruussuhteen kumoamiseen.

Tarkastellessaan Oikeusfilosofiassaan (1994 [1820], 180) kansalaisyhteiskuntaa ja työtä Hegel toteaa ammattien ja työn ympärille rakentuvan yhteisöjä, "teoreettisen ja käytännöllisen sivistyksen erityisiä järjestelmiä.” Niille on ominaista tehtävä, jonka kautta ne antavat panoksensa yhteiskunnan yhteiseen hyvään. Tähän tehtävään liittyvät arvot ja ammatilliset normit sekä osaamisen ja laadukkaan työn kriteerit. Niihin liittyy myös oikeudellinen vastuu toiminnasta, joka koskee erityisesti johtavassa asemassa olevia. Niin Hegel kun Honnethkin korostavat, että tunnustaminen työssä perustuu siihen panokseen, jonka yksilö tehtävässään antaa yhteisen hyvän saavuttamiseksi (Hegel 1994 [1820], 183; Honneth 2012).

Omassa Luennassani Pasasella ja Alanko-Turusella on taipumus rinnastaa vertaisuuden tunnustaminen Habermasin herruudesta vapaaseen dialogiseen suhteeseen. Rinnastaminen keskittyy kommunikaation luonteeseen eikä niinkään työn sisältöön, tehtäviin, arvoihin ja saavutuksiin. Kun tutkimuksen kohteena oleva koulutus edellyttää osallistujien pohtivan vertaisuutta, osallistujat luonnollisesti haluavat korostaa organisaatioasemista riippumatonta työtoveruutta, avoimuutta ja tasavertaista yhteistyötä. Tämän mukainen puhetapa tai orientaatio tulkitaan jaetuksi ja osalliseksi vertaisjohtamiseksi tai vertaisuuden tunnustamiseen perustuvavaksi johtamistavaksi.

Vertaisuuden ohella artikkeli tuo perustellusti esiin, että yhteisön pitäisi yhdessä sopia arvoistaan, tavoitteistaan ja pelisäännöistään sekä tavoista ja normeista, joilla työntekijät tukevat toisiaan työssä ja joilla tunnustus annetaan itse kunkin panoksesta yhteiseen hyvään. Tällaisessa viitekehyksessä korostuvat erilaisuuden ja yhteistyön voima sekä positiivisuus ja oikeudenmukaisuus palautteen antamisessa, kunnioittava suhtautuminen kaikkiin yhteisön jäseniin sekä päättäväisyys kaikenlaisen diskriminaation ja kiusaamisen eliminoimiseksi.

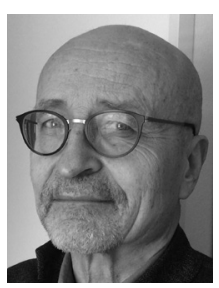

\section{REIJO MIETTINEN}

VTT, Helsingin yliopiston aikuiskasvatustieteen professori emeritus 
Buck-Morss, S. (2009). Hegel, Haiti and Universal History. Pittsburg: University of Pittsburg Press.

Cole, A. (2004). What Hegel's master/slave dialectics really means. Journal of Medieval and Early Modern Studies 34(3), 577-610.

Hegel. G. W. F. (1977[1807]). Phenomenology of Spirit. Translated by A. V. Miller with analysis of the text. Foreword by J. N. Findlay Oxford: Clarendon Press.

Hegel, G. W. F. (1994 [1820]). Oikeusfilosofian pääpiirteet eli luonnonoikeuden ja valtiotieteen perusteet. Oulu: Pohjoinen.

Honneth, A. (1996.) The Struggle for Recognition. The Moral Grammar of Social Conflicts. Cambridge, Mass.: The MIT Press.
Honneth, A. (2012). Labour and recognition: A redefinition. Teoksessa Honnteh, A. I and we. Studies in the Theory of Recognition. Cambridge: Polity, 56-74.

Taylor, C. (1994) Politics of recognition. Teoksessa Guttman, A. (ed.) Multiculturalism. Examining the Politics of Recognition. Princeton: Princeton University Press, 25-73.

Williams, R. R. (1997). Hegel's Ethic of Recognition. Berkeley: University of California Press.

\section{Löydä oma tiedelehtesi!}

Tiedon tähden -kiertue tekee tutuksi kotimaisia tiedelehtiä korkeakoulujen kampuksilla.

Tule tapaamaan lehdentekijöitä, osallistu luennoille ja työpajoihin. Ota tiedelehdet osaksi työtäsi ja opiskeluasi.

\section{Seuraavina vuorossa ovat}

- Kuopio, torstai 25.4., Kuopion kansalaisopisto

- Tampere, maanantai 20.5., Tampereen yliopiston päärakennus

- Vaasa, perjantai 24.5., Tritonia-kirjasto.

Mukana on yli 50 kotimaista tiedelehteä. Kiertuetta rahoittaa Suomen tiedekustantajien liitto.

Seuraa somessa tunnisteita \#tiedontahden \#vetandetleder ja \#knowledgefirst.

\section{Lisätiedot}

koordinaattori Esko Clarke Sario,

050554 1627,

tiedontahden@outlook.com

www.tiedekustantajat.fi

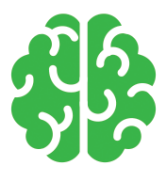

\section{TIEDON TÄHDEN}

VETANDET LEDER 